\title{
Separation of Fucosyltransferase and Endogenous Acceptors of Fucose from Human Parotid Saliva
}

\author{
R. Nakamura, S. Shizukuishi, T. Taniguchi, E. Iwasaki, S. Shibata, and A. 'Tsunemitsu \\ Department of Preventive Dentistry, Osaka University Dental School, \\ Kitaku, Osaka 530, Japan
}

Using gel filtration on Sephadex G-100 and column chromatography on CM-cellulose, fractions containing either endogenous acceptor of L-fucose or fucosyltransferase were obtained from human parotid saliva. Hydrolysis with mild acid followed by Smith degradation increased the fucosyltransferase activity of the fractions that contained endogeneous acceptor.

\section{J. Dent Res 56(7): 817-821 July, 1977.}

The oligosaccharide chains of human parotid glycoprotein contain more fucose than sialic acid in their end positions. ${ }^{1,2}$ Fucose is transferred enzymatically to galactosyl- or N-acetylglucosaminyl-glycoprotein from guanosine diphosphofucose (GDP-fucose) by the following reaction. ${ }^{3}$

$$
\underset{\text { glycoprotein }}{\stackrel{\text { fucosyltransferase }}{\text { fucosylglycoprotein + GDP }} \rightarrow}
$$

The presence of several types of $\alpha$-L-fucosyltransferase in submaxillary glands and stomach mucosal linings associated with serologically active structures of glycoprotein from either secretor or nonsecretor persons has been described. ${ }^{3,4}$ Our previous work has shown the presence of the enzyme, GDP-fucose: glycoprotein fucosyltransferase (EC 2. 4. 1.68) in human parotid and submaxillary-sublingual saliva, indicating the presence of the endogenous acceptor of fucose in human saliva. ${ }^{5}$

This paper describes the isolation of fuco-

Received for publication June 3, 1976.

Accepted for publication September 28, 1976.

This investigation was supported, in part, by Grant G-057179 in aid for Basic Scientific Research from the Education Ministry of Japan, 1975.

- Pharmacia Fine Chemicals AB, Uppsala, Sweden. many.

† Serva Entwicklungslabor, Heidelberg, West Ger-

$\$$ Sigma Chemical Co., St. Louis, Mo. syltransferase and endogenous acceptors of fucose in human parotid saliva from nonsecretor persons. Some characteristics of the endogenous acceptors are also described.

\section{Materials and Methods}

About $500 \mathrm{ml}$ of stimulated parotid saliva were collected from two nonsecretor persons of blood type A according to the method of Keene. ${ }^{6}$ Both donors were 28 years of age. Salivary flow was stimulated by the chewing of sweetened gum. The saliva was frozen and kept in a freezer (-20 C) until the $500 \mathrm{ml}$ was collected. The sample was fractionated with ammonium sulfate from 25 to $80 \%$ saturation. The precipitate obtained by centrifugation at $10,000 \mathrm{~g}$ was dissolved in approximately

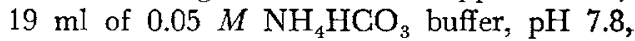
and dialyzed overnight against the same buffer. The procedures for further fractionation were similar to those described by Friedman, Merritt, and Bixler. ${ }^{7}$ The dialyzed sample was then separated by gel filtration on Sephadex G-100* $(2.0 \times 110 \mathrm{~cm})$. The fraction which was rich in carbohydrate (peak-1, not shown in Figure) was lyophilized, dissolved in $0.01 M$ acetate buffer, $\mathrm{pH} 5.6$, and then placed on a CMcelluloset column $(2.0 \times 18 \mathrm{~cm})$. Elution was achieved by successive additions of acetate buffer, $\mathrm{pH} 5.6$, at stepwise concentrations of 0.01 , $0.05,0.1,0.2$, and $0.5 \mathrm{M}$.

As a standard acceptor, fetuin free of both sialic acid and galactose was used and prepared from fetuin $\ddagger$ by mild acid hydrolysis with 0.05 $\mathrm{N} \mathrm{H}_{2} \mathrm{SO}_{4}$ at $80 \mathrm{C}$ for 60 minutes followed by Smith degradation. ${ }^{8}$ Fetuin and three endogenous acceptors of salivary glycoprotein which were separated by procedures described above were modified by the treatments with (1) mild acid hydrolysis, (2) mild acid hydrolysis followed by Smith degradation, and (3) mild acid hydrolysis followed by Smith degra- 
dation and $\beta$-hexosaminidase digestion. The digestion was achieved by incubating glycoprotein free of both sialic acid and galactose with the $\beta$-hexosaminidase $\$$ purified from Jack bean meal ( 7.0 units, $10 \mu \mathrm{g}$ of protein per $\mathrm{ml}$ reaction mixture) in $0.05 M$ sodium citrate buffer, pH 5.0 for 28 hours at 37 C.

The assay for GDP-fucose: glycoprotein fucosyliransferase was performed by the method described in a previous paper. ${ }^{5}$ The reaction mixture consisted of 50 pmoles of Tris-HCl buffer ( $\mathrm{pH}$ 7.2), 0.15 nmoles of GDP-L-14C-fucose* $(58,000 \mathrm{dpm}, 174 \mathrm{mCi} /$ $\mathrm{mM}$; radiochemical purity verified by paper chromatography as $98 \%$ ), aliquots of enzyme solution and $0.5 \mathrm{mg}$ of fetuin free of both sialic acid and galactose in a final volume of $0.5 \mathrm{ml}$. Incubations were carried out at $37 \mathrm{G}$ for 1 hour. At the end of incubation, the reaction was stopped by adding $5 \mathrm{ml}$ of $1 \%$ phosphotungstic acid in $0.5 \mathrm{~N}$ HCl. The resulting precipitate was washed five times with the same phosphotungstic acid solution. The precipitate was then solubilized in $0.5 \mathrm{ml}$ of NCS tissue solubilizert and the radioactivity was determined by liquid scintillation spectrometry with toluene scintillation fluid- 6 gm per liter of 2,5-diphenyloxazole (PPO), \$75 $\mathrm{mg}$ per

$\S$ Kindly supplied by Dr. Su-Chen Li, Tulane University, Covington, La.

* New England Nuclear, Boston, Ma.

† Amersham/Searle Corp, Arlington Heights, Il.

Packard Instrument Co, Inc, Downers Grove, II.

$\S$ Sigma Chemical Co, St. Louis, Mo. liter of 1,4-bis-2-(5-phenyloxazolyl)-benzene (POPOP). Control incubations were conducted by incubating the complete system ex. cept that the enzyme was replaced by enzyme inactivated at $100 \mathrm{C}$ for five minutes. Enzyme activity was expressed as dpm of ${ }^{14} \mathrm{C}$-fucose incorporated per hour per mg protein of enzyme solution. The enzyme activity due to the endogenous acceptor present already in the enzyme solution was termed the "endogenous activity."

Hexose was determined by a quantitative phenol-sulfuric acid assay ${ }^{10}$ and hexosamine was determined by the method of Reissig, Strominger, and Leloir. ${ }^{11}$ Protein was determined by the method of Lowry et al as modified by Hartree. ${ }^{12}$ D-Glucose, $N$-acetyl- $\beta$-D-glucosamine and recrystallized bovine albumin $\S$ were used respectively as a standard of these assays.

\section{Results}

Six fractions were separated by column chromatography on CM-cellulose and are designated Fr-I, Fr-II, Fr-III, Fr-IV, Fr-V, and Fr-VI (Fig 1). Fractions, Fr-II, Fr-III, and Fr-IV were rich in hexose, while the other fractions contained negligible amounts.

The procedures for separation of the endogenous acceptors from parotid saliva are given in Table 1 . When the fractions were incubated in the complete system, the enzyme activity was concentrated only in the Fr-VI, but not detected in the other fractions. Endo-

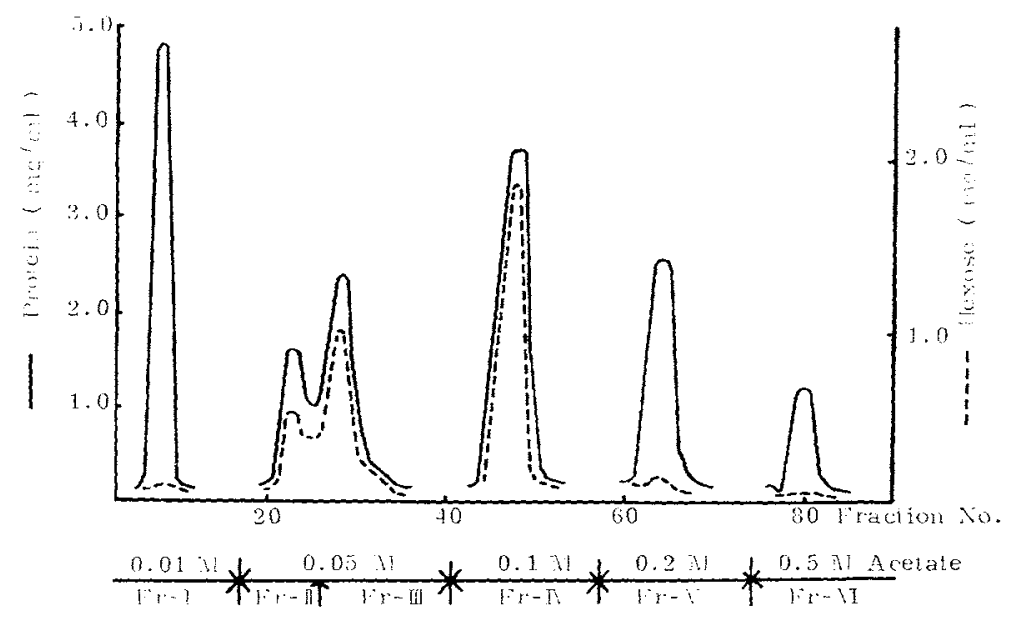

Fig 1.-CM-Gellulose column chromatography of carbohydrate rich fraction (peak-1) in parotid saliva. About $250 \mathrm{mg}$ protein were applied and 5-ml fractions were collected. 
TABLE 1

Isolation of Endogenous Acceptor from Parotid Saliva

\begin{tabular}{|c|c|c|c|c|c|}
\hline \multirow[b]{2}{*}{ Step } & \multirow{2}{*}{$\begin{array}{l}\text { Amount Used } \\
\text { for Assay } \\
\text { (mg as protein) }\end{array}$} & \multicolumn{4}{|c|}{ Enzyme Activity (dpm) } \\
\hline & & $\begin{array}{l}\text { Complete } \\
\text { System(a) }\end{array}$ & $\begin{array}{c}\text { Minus } \\
\text { Acceptor(b) }\end{array}$ & $\begin{array}{l}\text { Inactivated } \\
\text { Enzyme(c) }\end{array}$ & $\underset{\text { (a) }-(\mathrm{c})}{\Delta \mathrm{dpm}}$ \\
\hline Grude & 0.51 & 2795 & 252 & 45 & 2750 \\
\hline $\begin{array}{l}\text { Ammonium sulfate } \\
\text { fractionation } \\
\text { Gel filtration on }\end{array}$ & 2.12 & 11415 & 2017 & 74 & 11341 \\
\hline $\begin{array}{l}\text { Gel filtration on } \\
\text { Sephadex G-100 } \\
\text { Chromatography on }\end{array}$ & 1.63 & 16880 & 1846 & 90 & 16790 \\
\hline CM-cellulose & & & & & \\
\hline Fr-I & 0.39 & 56 & 28 & 54 & 2 \\
\hline Fr-II & 0.17 & 52 & 32 & 55 & - \\
\hline Fr-III & 0.28 & 61 & 30 & 64 & - \\
\hline Fr-IV & 0.31 & 61 & 31 & 60 & 1 \\
\hline Fr-V & 0.28 & 58 & 33 & 62 & - \\
\hline Fr-VI & 0.07 & 9362 & 35 & 60 & 9302 \\
\hline
\end{tabular}

genous activity was high in whole parotid saliva and in peak-1. Further fractionation of peak-1 on CM-cellulose resulted in the activity disappearing completely. No endogenous activity was found in the active enzyme fraction, Fr-VI. A summary of the partial purification of fucosyltransferase from human parotid saliva is described in Table 2. An approximately 21 -fold purification of enzyme activity was obtained in Fr-VI.

Characteristics of the endogenous acceptors were further investigated. For this, each fraction other than Fr-VI was used as salivary acceptor and Fr-VI was the source of enzyme. Fetuin and its preparations were also tested serving as acceptor controls. As shown in Table 3 , the highest acceptor activity was found in Fr-IV which was eluted from CM-cellulose column with $0.1 M$ acetate buffer. Two frac- tions of Fr-II and Fr-III also exhibited activity whereas no activity was found in Fr-I and FrV. When each of Fr-II, Fr-III, or Fr-IV was modified by mild acid hydrolysis and continuous Smith degradation before use, the activity increased remarkably in each fraction with every additional treatment. Enzymatic digestion of these fractions with $\beta$-hexosaminidase purified from Jack bean meal destroyed the fucose acceptor. Similar behavior was found with fetuin and its preparations.

\section{Discussion}

The composition of glycoprotein in human parotid saliva has been determined by several investigators. 1,2 The main glycoprotein was basic, rich in proline, glycine and glutamic acid, had a molecular weight of 36,000 and

TABLE 2

Partial Purification of $\alpha$-L-Fucosyltransferase

\begin{tabular}{|c|c|c|c|c|c|c|}
\hline Step & $\begin{array}{c}\text { Total } \\
\text { Volume } \\
(\mathrm{ml})\end{array}$ & $\begin{array}{c}\text { Total } \\
\text { Protein } \\
\text { (mg) }\end{array}$ & $\begin{array}{c}\text { Total } \\
\text { Activity } \\
\left(\times 10^{5} \mathrm{dpm}\right)\end{array}$ & $\begin{array}{l}\text { Specific } F \\
\text { Activity* }\end{array}$ & $\begin{array}{l}\text { Recovery } \\
(\%)\end{array}$ & $\begin{array}{l}\text { Purification } \\
\text { (fold) }\end{array}$ \\
\hline Crude & 500 & 1275 & 68.8 & 0.625 & 100 & 1 \\
\hline $\begin{array}{l}\text { Ammonium sulfate } \\
\text { fractionation } \\
\text { Gel filtration on }\end{array}$ & 19.2 & 811 & 43.6 & 0.537 & 63 & 0.86 \\
\hline $\begin{array}{l}\text { Sephadex G-100 } \\
\text { Chromatography on }\end{array}$ & 9.2 & 278 & 41.8 & 1.11 & 61 & 1.78 \\
\hline $\begin{array}{l}\text { CM-cellulose } \\
\text { (Fr-VI) }\end{array}$ & 2.0 & 7.1 & 16.0 & 13.1 & 23 & 21.0 \\
\hline
\end{tabular}

* Specific activity is expressed as the activity per milligram of protein. 
TABLE 3

Characteristigs of Endogenous Acceptors

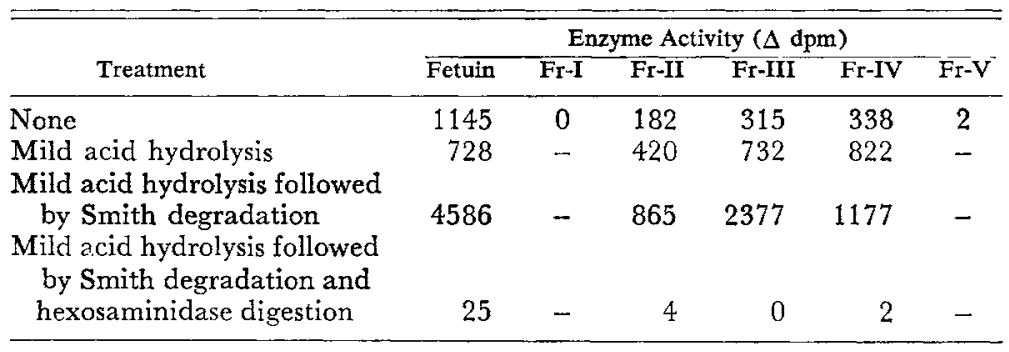

Note: $\Delta \mathrm{dmp}$ was calculated by subtracting the activity (dpm) of control incubation from that of complete system.

contained $57.5 \%$ protein and $39.7 \%$ carbohydrate. ${ }^{2}$ A recent study by Friedman, Merritt, and Bixler ${ }^{7}$ indicated that several forms of this group of glycoproteins were present in human parotid saliva. The mole ratios of the sugar residues of their carbohydrate side chains and their charge densities were different.

Human parotid saliva was separated into six fractions by gel filtration on Sephadex G-100 followed by column chromatography on CMcellulose. In these procedures, fucosyltransferase was successively separated from the fractions containing endogenous acceptors. Three fractions, Fr-II, Fr-III, and Fr-IV, which were rich in carbohydrate, possessed an endogenous acceptor.

In general, the acceptor site of the sugar residue of glycoprotein for the fucosyltransferase is considered to be either galactose or $\mathrm{N}$ acetylglucosamine on the basis of sugar arrangement. ${ }^{3}$ The sugar residues and their arrangement in salivary glycoprotein may resemble those of fetuin which has at the end of its oligosaccharide chains, sialic acid, galactose and $\mathrm{N}$-acetylglucosamine in that order. ${ }^{8} \mathrm{Spiro}^{8}$ has demonstrated, by treatment of fetuin with mild acid hydrolysis followed by Smith degradation, that the $\mathrm{N}$-acetylglucosamine residue of the oligosaccharide chains is exposed. When the $\mathrm{N}$-acetylglucosamine residue of the oligosaccharide chains was exposed by the same treatment, the highest fucosyltransferase activity appeared in Fr-II, Fr-III, and Fr-IV as well as fetuin. As a next step, the enzymatic digestion with exo-type of $\beta$-hexosaminidase isolated from Jack bean meal was carried out. This enzyme is known to release the $\mathrm{N}$-acetylglucosamine residue from the oligosaccharide chains. By this digestion, fucosyltransferase activity completely disappeared in each treated fraction and in treated fetuin. These findings, therefore, strongly suggest that the enzyme catalyzes the transfer of L-fucose to $\mathrm{N}$-acetylglucosamine residue of oligosaccharide chains in salivary glycoprotein.

Both the rative fetuin and desialyzed fetuin functioned as acceptors although $\mathrm{C}_{4}$ position of $\mathrm{N}$-acetylglucosamine is occupied by binding to galactose. All three fractions from parotid saliva and the fractions modified by mild acid hydrolysis were able to function as acceptors. The presence of 2-, 3-, and 4- $\alpha-\mathrm{L}-$ fucosyltransferase in submaxillary glands from persons who are secretors of $\mathrm{ABH}$, and of 3-, and 4- $\alpha$-L-fucosyltransferase in tissues from nonsecretor persons, is reported by Chester and Watkins. ${ }^{3}$ They described that the 2-fucosyl linkage which means the binding to galactose was always detected in the products formed with enzyme preparations from secretors whereas this linkage was not found in the products by the submaxillary gland preparations from nonsecretors. The evidence presented seems to support the suggestion that acceptor site of L-fucose is located at $\mathrm{C}_{3}$ position of the $\mathrm{N}$-acetylglucosamine. This study was only with the parotid saliva of nonsecretors of blood type A. Studies are in progress on the enzymatic properties associated with other blood-group characteristics and secretor status.

\section{Conclusions}

Endogenous acceptors of L-fucose in human parotid saliva were separated into three fractions by gel filtration on Sephadex G-100 and column chromatography on CM-cellulose. Fucosyltransferase activity was increased about 21 -fold by these procedures. When the three fractions were modified by mild acid hydroly- 
sis followed by Smith degradation, the enhanced fucosyltransferase activity was found in each fraction. The results suggested that the fucosyltransferase from human parotid saliva in nonsecretors of blood type A catalyzes the transfer of fucose from GDP-fucose to the $\mathrm{C}_{3}$ position of $N$-acetylglucosamine residucs of the endogenous acceptors.

The authors are grateful to Dr. Su-Chen Li, Delta Regional Primate Research Center, Tulane University, Covington, Louisiana, for his generous gift of the purified Jack bean $\beta$-hexosaminidase.

\section{References}

1. Mandel, I.D.; Hampar, B.; Thompson, R.H., JR.; and Ellison, S.A.: The Carbohydrates of Human Parotid Saliva, Arch Oral Biol 3:278-282, 1961.

2. LeVIne, M.J.; EliISon, S.A.; and BaHL, O.P.: The Isolation from Human Parotid Saliva and Partial Characterization of the Protein Core of a Major Parotid Glycoprotein, Arch Oral Biol 18:827-837, 1973.

3. Watkins, W.M.: Blood-Group Specific Substances, in Gotrschalk, A. (ed): Glycoproteins; Their Composition, Structure and Function, 2nd ed., Amsterdam: Elsevier, 1972, pp 830-891.

4. Ghester, M.A., and Watkins, W.M.: $\alpha$-LFucosyltransferases in Human Submaxillary Gland and Stomach Tissues Associated with the $\mathrm{H}, \mathrm{Le}^{\mathrm{a}}$ and $\mathrm{Le}^{\mathrm{b}}$ Blood-Group Characters and $\mathrm{ABH}$ Secretor Status, Biochem Biophys Res Commun 34:835-842, 1969.

5. Nakamura, R., and Tsunemitsu, A.: The Presence of Guanosine Diphosphofucose: Glycoprotein Fucosyltransferase in Human Saliva, J Dent Res 54:417, 1975.

6. Kenne, H.J.: Parotid Fluid Collection System with Vacuum-Trap Modification, $J$ Dent Res 42:1041, 1963.

7. Friedman, R.J.; Merritt, A.D.; and BrxLER, D.: Immunological and Chemical Composition of Heterogeneous Basic Glycoproteins in Human Parotid Saliva, Biochim Biophys Acta 230:599-602, 1971.

8. SpIRo, R.G.: Periodate Oxidation of the Glycoprotein Fetuin, J Biol Chem 239:567$573,1964$.

9. $\mathrm{LI}_{\mathrm{s}}$ S.C., and LI, Y.T.: Studies on the Glycosidases of Jack Bean Meal. III. Crystallization and Properties of $\beta-\mathrm{N}$-Acetylhexosaminidase, J Bio Chem 245:5153-5160, 1970.

10. Dubois, M.; Gilles, K.A.; Hamilton, J.K.; Rebers, P.A.; and Smith, F.: Colorimetric Method for Determination of Sugars and Related Substances, Anal Chem 28: 350-356, 1956.

11. Reissig, J.L.; Strominger, J.L.; and LeLOIR, L.F.: A Modified Colorimetric Method for the Estimation of N-Acetylamino Sugars, J Bio Chem 217:959-966, 1955.

12. Hartree, E.F.: Determination of Protein: A Modification of the Lowry Method That Gives Linear Photometric Response, Anal Biochem 48:422-427, 1972. 